\title{
"Mnichov" jako morální narativ českých dějin. Českožidovská stanoviska v komparaci s většinovými postoji
}

\author{
"Munich" as the moral narrative of Czech history. \\ Czech-Jewish views compared to majority attitudes
}

DOI: 10.31577/EtnoRozpra.2021.28.2.02

\section{Blanka Soukupová}

\section{Abstract}

"Munich" (the Munich Agreement of September $29^{\text {th }}-30^{\text {th }}, 1938$ ) paved the way for the destruction of the First Republic's liberal democracy. The influence of foreign political powers played a decisive role in this destruction. Very soon afterward, doubts regarding the sovereignty of the state were even expressed by political representatives of the Second Republic, who understood the "new" Czechoslovakia as part of German Central Europe. Immediately following September 30 ", Czech society began to question whether "Munich" was a betrayal by the "immoral" Western powers, who ignored their Allied commitments in exchange for a dubious peace, or perhaps it was a moral punishment from history or even God for the alleged fatal mistakes of First Republic democracy, now being visited upon the citizens of the Second Republic. At the same time, of course, the public also questioned the morality of the military capitulation of a small nation, an issue which was also repeatedly raised by Czechoslovak historiographers and mass media after the liberation of Czechoslovakia in May of 1945. While after September 30 ${ }^{\text {th }}$, 1938 and shortly after the liberation of Czechoslovakia the moral narrative was ideologically and politically structured (the Czech-Jewish movement understood Munich as a moral failure of all of Europe), in the final weeks of the Second Republic, during the Protectorate of Bohemia and Moravia and after the February coup (with the exception of the Prague Spring), a single "official" view prevailed. Following the February coup (1948), this view was also adopted by Czech Jews. The objective of this study is to analyse the meaning and ways in which "Munich" was moralized after September 30 ${ }^{\text {th }}$, 1938, from May 1945 to February 1948, after the February coup, in the "golden sixties" and during the years of "normalization". At the same time, it demonstrates that "Munich" was used to legitimize period political interests and create socio-political capital. 


\section{Key words}

moral narrative, Czech history, Munich, Czech-Jewish movement

\section{Klúčové slová}

morálny naratív, české dejiny, Mníchov, českožidovské hnutie

\section{Acknowledgment}

Text byl vypracován v rámci programu Progres Q 22 FHS UK.

\section{Kontakt / Contact}

doc. PhDr. Blanka Soukupová, CSc., Fakulta humanitních studií, Univerzita Karlova, Pátkova 2137/5, Praha 8, 182 00, Česká republika, e-mail: 6446@mail.fhs.cuni.cz

ORCID (iD) https://orcid.org/0000-0001-6201-9493

\section{Ako citovat' / How to cite}

Soukupová, B. (2021). „Mnichov“ jako morální narativ českých dějin. Českožidovská stanoviska v komparaci s většinovými postoji. Etnologické rozpravy, 28(2), 24-36.

https://doi.org/10.31577/EtnoRozpra.2021.28.2.02

\section{Úvod}

Mnichovská dohoda (29. - 30. zárí 1938) a její důsledky, tzv. Mnichov, patří ke klíčovým událostem moderních českých i československých dějin a současně také k nejvděčnějším tématům české historiografie, publicistiky i umění. I když se život drtivé většiny pamětníků této národní tragédie již uzavřel, v okamžicích společenskopolitických zvratů se znovu a znovu argumentuje právě tzv. mnichovskou zkušeností. Zničení prvorepublikové demokracie, jež byla zdrojem většinové národní hrdosti, vnějšími politickými silami, však neznamenalo pouze politickou a hospodářskou tragédii (Gebhart, Kuklík, 2004: 26, 163 180; Hájek, 1959: 22; Křen, 1963: 98-99; Kural, 1994: 5, 36; Moulis, 1979: 16; Pasák, 1999: 220). S až neuvěřitelnou rychlostí došlo totiž i k destrukci československé prvorepublikové demokracie. V novém svébytném státním útvaru začala diskuse o tom, kdo k nám (ne) patří. Do kategorie cizinci byli zahrnuti nejprve uprchlíci (Gebhart, Kuklík, 2004: 171-172; Kural, 1994: 19-20; Rataj, 1997: 12-14; Rothkirchen, 2005: 78-80), tedy německožidovští, židovští a němečtí běženci z nacistického Německa, z Rakouska, právě tak jako nečeští běženci z pohraničí. Dále byli do této kategorii začleněni i tzv. němečtí Židé, tedy ti, kteří se ve sčítáních lidu (poslední se konalo v roce 1930) přiklonili k německé národnosti. Jen o něco málo později byli vystaveni nacionalistickým útokům i Češi židé, tedy ti, kteři se cítili národnostně Čechy a židovství vnímali v poloze náboženství, pưvodu, rodinných kořenů nebo etiky. ${ }^{1}$ Krajně pravicový režim však viděl $v$ obecné rovině nepřátele

1 K nárůstu antisemitismu Bednařík, 2016: 198-221; Frankl, 2009; Gebhart, Kuklík, 2004: 187-195; Kárný, 1989; Nakonečný, 2006: 157-162; Pasák, 1999: 227-239; Pejčoch, 2011: 138-141; Rataj, 1993; Rataj, 1994; Rataj, 1997: 93-119; Rataj, 2007: 32-34; Soukupová, 2007: 93-94; Soukupová, 2008; Soukupová, 2013: 34, 40-50, 66; Šebek, 2016: 56-72. 
i v demokratických Čechoslovácích. Pravděpodobně nejznámější je př́ípad spisovatele a novináře Karla Čapka, vystaveného útokům českých fašistů (Kudělka, 1987). Dozvuky druhorepublikového selhání společenských elit, dovršené v období protektorátu Čechy a Morava, však pocit’ujeme dodnes. Česká společnost tak stále žije „s Mnichovem za zády“, ${ }^{2}$ jakkoliv jsme konfrontováni s propadem jejích historických znalostí.

Takřka bezprostředně po 30. záŕí 1938 se však „Mnichov“, když přijaly dohodu ústavní orgány první Československé republiky, začal posuzovat i z hlediska etických hodnot. Posléze se pak transformoval na jeden z nejvýznamnějších morálních narativů české minulosti. Česká veřejnost si kladla především otázky, kdo zavinil „Mnichov“, ${ }^{3}$ zda má malý národ tvárí v tváŕ velkým dějinám morální oprávnění k vojenské kapitulaci a jaké strategie je morální přijmout po kapitulaci. „Mnichovem“ se však začaly rovněž posuzovat poválečné dějiny Československa. Hesla typu Již nikdy Mnichov! tak navozovala paradoxně legitimitu nového poúnorového totalitního režimu, nastoupeného vazalsky promoskevského kurzu zahraniční politiky i domácích represí vůči tzv. buržoazii.

\section{Morální apely ve většinovém veřejném prostoru bezprostředně po 30. záríi 1938}

Ve své slavné básni Zpěv úzkosti ze sbírky Torso naděje František Halas (1940: 20-21) morálně odsoudil Francii a Anglii, spojence první Československé republiky, jako zrádce, kteří nedodrželi mezinárodněpolitické závazky. S obdobným morálním odsouzením Francie se setkáme i v časové básni Vladimíra Holana Uražení a ponížení ze sbírky Zárí 1938 (Holan, 1938: 26). Byli to tedy právě básníci, kteří dokázali velmi přesně zachytit nálady v české společnosti. Motiv zrady však rozvíjely i politické strany, které vytvořily na konci listopadu 1938 vládnoucí Stranu národní jednoty (Soukupová, 2016b: 20). Naproti tomu politický katolicismus viděl hlavního viníka „Mnichova“ v prvorepublikové demokracii, jež se údajně odklonila od tzv. tradičních hodnot, zejména pak od svatováclavské tradice (Soukupová, 2016b: 21). „Mnichov“ tak mohl být interpretován i jako morální trest uvalený na občany tzv. druhé republiky „dějinami“ nebo dokonce Bohem za údajně osudové chyby první republiky, za její velikášství. Naopak demokratické politické subjekty stylizovaly po „Mnichově“ český národ či Československo do role oběti krátkozraké francouzské a britské politiky s její naivní představou o uchování míru v Evropě (Soukupová, 2016b: 22). Právě status obětovaného národa (státu) se svým velkým morálním potenciálem ospravedlňoval kapitulaci československé armády a snímal z ní jakékoliv obvinění ze zbabělosti. To odpovídalo i náladám v tehdejší české společnosti, která byla bezesporu $v$ tzv. mnichovských dnech připravena jít do nerovné války s nacistickým Německem. Z četných vzpomínek, jež toto tvrzení podporují, vybírám tu od literárního vědce, kritika a překladatele Václava Černého (1994: 371-372):

Cítil jsem na tom Dobrošově [vojenská pevnost - poznámka BS] přímo fyzicky, že se náš lid právě ocitl na jednom z dějinných vrcholů sebe samého, že uzrál k hrdému

\footnotetext{
2 Tento obrat jsem si vypůjčila z úvahy Kuklík, Roček, Zátka, 1969. Srov. však i název a obsah knihy Kuklík,
} Němeček, Šebek, 2011.

3 Tato otázka se pak opakovaně vracela. Srov. např. Ústav pro mezinárodní politiku a ekonomii, 1959. 
ztotožnění se svou svobodou, že se cítí povolán. Chtěl se osvědčit i v boji, byl v tu chvíli veliký. Cítil jsem také, že by bylo tragicky nebezpečné jeho sebevědomí z tohoto vrcholu srážet zbabělostí, kapitulací. Prožíval jsem okamžiky radostné exaltace a blížící se válku jsem si bezmála přál! Přímo mne trýznila vnitřní potřeba, aby se mravní pravdivost nového češství osvědčila činem, a v ní abych si mohl osvědčit sám sebe!

Československý prezident Edvard Beneš ospravedlňoval kapitulaci argumentem fyzického přežití národa.

Když Beneš kapituloval, myslím, že kapituloval ze dvou důvodů. Předně byl smrtelně raněn ... zradou Francie a Ihostejností Anglie. Za druhé - snad - snad měl na mysli onu biologickou podstatu národa a řekl si, že není jeho právo toto obětovat zejména tenkrát, když by byl boj beznadějný,

vzpomínal ve vysílání Svobodné Evropy novinář Ferdinand Peroutka, poúnorový emigrant (Peroutka, 1995: 130). ${ }^{4}$ O kvalitách první republiky však Beneš nezapochyboval ani na okamžik. ${ }^{5}$

Opoziční komunistická strana již po „Mnichovu“ naopak poukazovala na údajnou zradu egoistické „buržoazie“, jež se zalekla pomocné ruky podané údajně zcela nezištně Sovětským svazem (Soukupová, 2016b: 25). Tento mýtus šírila po druhé světové válce jak komunistická publicistika, tak krásná literatura. "Svár demokracie a totality“ se však projevil i v názorech na pomnichovské směrování společnosti. Zatímco pravicové a ultrapravicové síly vykládaly jako zcela morální nastupující nacionální egoismus, demokratická veřejnost tuto strategii odsuzovala jako konjunkturální popření prvorepublikových tradic (Soukupová, 2016b: 29). Již v polovině října 1938 představila fašistická Národní republika tzv. druhou republiku jako lod', jež se musí zbavit přítěže židovských advokátů, lékařů a finančníků (Soukupová, 2016b: 32). Naprostý propad demokracie si můžeme demonstrovat i na úvodníku Ferdinanda Peroutky v Př́tomnosti (Soukupová, 2000: 70-78). „Cizí lidé nám zmenšili území hmotné, a ted’ nám sami naši ještě zmenšují naše území duchovní... Ne ztracená území, ale toto je národní katastrofa!“ moralizoval malîr a spisovatel Josef Čapek (1970: 208).

4 „Mnichov“ a kapitulace však zůstaly pro Beneše doživotním politicko-morálním traumatem. „Když jsem se po válce vrátil z koncentračního tábora a poprvé jsem se setkal s Benešem, bylo vidět, jak v něm ta otázka stále žije. Udělal-li dobře, když se rozhodl nevést válku. Ještě ve dveřích, když se zeptal: ,Jak se máte?’ jeho druhá otázka byla: ,Neudělal jsem tenkrát dobře?‘ Myslil tím, že obětí by bylo daleko, daleko méně, než bylo, kdyby se vedla válka s Německem," vzpomínal dále Peroutka (1995: 130). V Benešových pamětech se pak dočteme, že otázku bojovat či kapitulovat rozhodl „Z hlediska československého a evropského, z hlediska lidského - čestně a správně“ (Beneš, 1968: 342).

5 Ve svém rozhlasovém projevu z 10. zárí 1938 Beneš uvedl: „Naše republika se po celých dvacet roků vyvíjela v klidu a pokroku; politické demokracie a svobody, hospodářského a civilizačního obohacení, vzestupu kulturního, náboženské tolerance, sociální spravedlnosti dosahovala krok za krokem bez krizí, bez pučů a revolucí, pokojně a vývojově. Co jinde působilo nebezpečné přesuny, ba převraty, u nás se řešilo rozumně, bez slepé vášně, prakticky“ (Beneš, 1968: 484).

6 Srov. zejména druhý díl trilogie Marie Pujmanové Hra s ohněm (1947: 277-287). 


\section{Českožidovské stanovisko k „Mnichovu“ po 30. zárí 1938}

V českých zemích v prvorepublikovém Československu žilo v roce 1921 v Čechách 79 777, na Moravě 37989 a ve Slezsku 7317 osob židovské víry. V roce 1930 to bylo v Čechách 76301 osob a na Moravě a ve Slezsku 41250 osob. K židovské národnosti se hlásilo v roce 192111251 osob v Čechách, 15335 osob na Moravě a 3681 ve Slezsku. Ve druhém sčítání uvedlo židovskou národnost 15697 osob v Čechách a 21396 osob na Moravě. V roce 1921 se z těch, kteří se přihlásili k židovské vir̃e, hlásilo 38 procent k české národnosti (43 350 osob), 34,7 procenta k národnosti německé (39 629 osob) a 25,9 procent k národnosti židovské. ${ }^{7}$ Pomnichovské pohledy českožidovského hnutí, které se snažilo oslovit především osoby židovské víry s českou národností, případně Čechy židovského původu, můžeme charakterizovat jako velmi emocionální. Českožidovský tisk vyjadřoval své zklamání jak z postoje velmocí (nebo přesněji jejich vládnoucích garnitur, Soukupová, 2007: 87), které obětovaly Československo, tak z „ostudné“ kapitulace československé vlády (Soukupová, 2016c: 165-166, 170). Svaz Čechů-židů v Československé republice, ústřední korporace českožidovských asimilantů, začala okamžitě shromažd'ovat materiální prostředky a peníze pro uprchlíky z pohraničí, aniž by je rozlišovala podle jejich jazyka, národnosti nebo politické orientace (Soukupová, 2016c: 168). Tento postoj čerpal ze židovského principu nedělitelnosti morálky. Druhý zdroj českožidovské morálky vyvěral ovšem z osvícenství: Češi-židé cítili hluboký závazek k zemi, kde se narodili (Soukupová, 2016c: 174) a která se ocitla nyní v ohrožení. Proto také na oficiální úrovni v prvních pomnichovských týdnech odmítali emigraci. Negativních konotací zbavili vystěhování z Československa až na počátku roku 1939, na pozadí př́prav antisemitské legislativy (Soukupová, 2016c: 186-189; Soukupová, 2007: 90-91, 97-98). Jako morální bylo chápáno i setrvání v židovských náboženských obcích; z dosud shromážděných dat je zřejmé, že se výstupy týkaly pouze stovek osob (Soukupová, 2007: 97). Samotný „Mnichov“ nechápali ovšem Češi židé jako československou záležitost, ale jako morální pád celé Evropy. ${ }^{8}$ Prudkou eskalaci antisemitismu v tzv. druhé republice charakterizovali jako „nespravedlnost“ k loajálnímu židovskému obyvatelstvu. V duchu židovské tradice si ovšem položili i otázku možného vlastního selhání (především používání němčiny na veřejnosti, přílišné zastoupení v tzv. neproduktivních oborech), jež mohlo snad protižidovskou nenávist posílit (Soukupová, 2016c: 181, 186). Vưči demokratickým německým a německožidovským uprchlíkưm však pravidlo nedělitelnosti morálky přece jenom porušili: tito běženci měli mít nárok pouze na bezpečný odchod z Československa, nikoliv na nový domov v jeho hranicích (Soukupová, 2016c: 182-183).

7 Na „ostatní“ národnosti připadla 1,4 procenta (šlo o 1586 osob). Srov. Machačová, Matějček, 1999: 116.

8 „Evropa prožila svůj největší morální pád; Evropa ... se vzdala práva, ustupujíc násilí,“ napsal českožidovský týdeník Rozvoj (Konec jednoho údobí, 1938: 1). 


\section{Židovské stanovisko k „Mnichovu“ po osvobození Československa (květen 1945)}

Po osvobození Československa v květnu 1945 se stal „Mnichov“ významným nástrojem $\checkmark$ boji o politickou moc. Interpretace mnichovských událostí propagandou Komunistické strany Československa, tehdejší nejvlivnější politické strany, zůstala neměnná: v Mnichově měly zradit Československo západní mocnosti i domácí politická garnitura (zejména sociální demokracie, tedy hlavní poválečná politická rivalka komunistické strany) na čele s Edvardem Benešem, v termínu komunistického redaktora Gustava Bareše „česká reakce“ (Bareš, 1948: 11, 14, 30). Jedinou politickou silou bojující proti „Mnichovu“ tak údajně zůstala komunistická strana. To také založilo její poválečný politický kapitál. Tento výklad mnichovských událostí se přitom po druhé světové válce odehrával na pozadí adorace Sovětského svazu a Rudé armády, jež měly Československo zachránit před naprostou zkázou (Soukupová, 2016: 13-14).

Leitmotivem židovské veřejnosti, po druhé světové válce zprvu ideologicky nestrukturované, se stalo neopakování Mnichova, který měl otevř́t cestu k 14. (tehdy vznikl samostatný Slovenský štát) a 15. březnu 1939 (15. března začala násilná okupace nacistickým Německem). $V$ tomto duchu se vyslovil také Kurt Wehle, reprezentant Rady židovských náboženských obcí, na manifestaci slovenských Židů v Bratislavě 16. března 1939, tedy ve výroční den vyhlášení protektorátu Čechy a Morava (1939). Právě 16. březen byl totiž rozhodujícím datem z hlediska státoprávního, protože tehdy Adolf Hitler vydal Výnos o zřízení Protektorátu Čechy a Morava (tzv. Erlass). Ve výroční den Wehle současně zdůraznil morální postoj Židů v záŕí 1938: Židé republiku nezradili a později bojovali na všech frontách druhé světové války i v partyzánských jednotkách za její osvobození (Slovo k židům na Slovensku, 1946: 17-18). Germanista Pavel Eisner pak v atmosféře zpochybňované či popírané židovské loajality vůči republice vyzdvihl bytostné sepětí mnohých Židů s Československem:

\footnotetext{
Nedlouho po Mnichovu se zastřelil Petschkův ředitel Taussig ... Člověk s téměř neomezenými možnostmi hmotnými, s volným výjezdem do kolikeré ciziny, člověk, na kterého venku dychtivě čekali. Neslyšel jsem nikdy, že Petschkův ředitel Taussig byl náčelníkem pražské župy sokolské, a nevím věru, jakým byl češtinářem. Ale ten Petschkův ředitel Taussig zavrhl odjezd do ciziny v jeho případě věru neriskantní a volil smrt. Nedovedl odejít. Šéfredaktor Thomas (Teweles) se po Mnichově otrávil se svou ženou. V Londýně na něho čekalo půl jeho pražské redakce, čekaly na něho jeho osobní styky doslova světové. A tento člověk nijak „těžký“ letorou, vášnivě oddaný všem radostem života, volil sebevraždu. Motiv: že by už neviděl Hradčany a neměl Prahu (Eisner, 1946: 59).
}

Také Štěpán Engel se zastal tzv. německých Židů, když je obvinil na konferenci předsedů ONV a OSK dne 20. února 1946 ministr vnitra Václav Kopecký jako údajné Němce z podílu na mnichovské katastrofě, která byla předstupněm nacistické okupace. „Osudové zrady“ se podle něj dopustili př́slušníci Henleinovy Sudetoněmecké strany, na něž mají také výhradně dopadnout prezidentské dekrety (Engel, 1946: 18-19). 


\section{Židovské stanovisko k „Mnichovu“ po únorovém převratu (1948)}

Již v roce 1947 psal historik Miroslav Kárný v komunistické Tvorbě o tzv. mnichovské politice. Nazýval tak politiku, jež měla směrovat německý nacismus proti Sovětskému svazu (Soukupová, 2016a: 466). Po únorovém převratu (1948) převzala židovská reprezentace argumentaci a rétoriku komunistické strany. „Mnichov“ byl nadále vykládán jako zrada, která otevřela cestu k 15. březnu 1939, a současně jako začátek tragédie českých Židů. Novou součástí menšinového morálního narativu byli však další údajní viníci této zrady. V úvaze Karla Kreibicha, německého komunistického intelektuála, ze 17. září 1948 byli z podílu na katastrofě obviněni židovská „buržoazie“ a část židovských intelektuálů, kteří se údajně byli ochotni spojit v krizových letech s reakcí, nebo se alespoň stranili politického zápasu. Po únorovém převratu pak jako emigranti začali připravovat nový Mnichov. Stejně si měli počínat i tehdejší představitelé světového sionistického hnutí (Kreibich, 1948: 405-406). „Čeští, 'demokraté, kteří svojí kapitulantskou politikou zavinili mnichovskou katastrofu a tím i mučení a usmrcení tisíců židů a byli únorovými událostmi z veřejné činnosti v lidové demokracii odstraněni, kují nyní zrádcovské pikle proti republice spolu s protektory fašismu, nacismu a antisemitismu. Přitom se sbratřují ve spolupráci s odsunutými henleinovci. Tak se připravuje nový Mnichov,“ napsal Kreibich (Kreibich, 1948: 406). Komunistická propaganda přitom záměrně nezdůraznila, že Benešova abdikace i přijetí smlouvy byly výsledkem nátlaku jak ze strany zahraniční, tak ze strany domácí politiky.

Stejný morální narativ ovšem zazníval i v letech politických procesů s významným antisemitským laděním a jejich dozvuků ve druhé polovině padesátých let minulého století. Morální poselství „Mnichova“ mělo židovské obyvatelstvo dovést k přesvědčení, že „židovskou otázku“ je možné vyřešit pouze v rámci socialistického zrrízení a že místo Židů je výhradně v řadách nadšených budovatelů nového světového řádu pod záštitou Sovětského svazu. Neomluvitelné byly nejen postoje nepřátelské vůči socialismu, ale i politická pasivita. Naplno se tak začalo uplatňovat heslo Kdo není s námi, je proti nám. Ve stejném duchu jako Kreibichův úvodník napsal v roce 1951 svưj úvodník s příznačným názvem Když zrada byla dokonána i Štěpán Kisch, bratranec levicového žurnalisty Egona Erwina Kische, představitel židovské náboženské obce, jenž dokazoval, že „Mnichov“ byl důsledkem kapitalistického řádu, na jehož upevňování se podíleli i někteří Židé. Současně však Kisch vyzdvihl židovský odboj, i když pouze ten na východní frontě:

Naši souvěrci se vyrovnávali různě s událostmi doby, které se přímo překotně hrnuly. Jistěže všichni nenáviděli Hitlera a jeho hordy. Jistěže všichni odsuzovali zradu, jíž padla za obět' naše vlast, avšak jen malá menšina uvědomovala si pozadí a př́činné souvislosti této katastrofy. Jen mizivé menšině bylo jasno, kdo je jejím vlastním a úhlavním nepř́telem, proč došlo k této pohromě, která strhla i je s sebou do propasti ... Horní a střední vrstvy židů měly zato, že je možno státi stranou světového dění, že je možno prostě se prohlásit ,neutrálním‘ a přehlédly úplně, že právě touto ,neutralitou' přihrávají úhlavnímu nepř́teli ... Mnichovská zrada a její následky, k nimž patří i okupace zbytku republiky dne 15. března 1939, postihla velkou část našich souvěrců proto tak tvrdě, protože prostě nebyli připraveni na naprosto logický průběh událostí ... Pohroma ... byla jen logickým důsledkem zvráceného společenského řádu, 
jehož zákony jsou zaměřeny jedině k tomu, aby chránily a udržovaly majetek a moc nepatrné skupiny lidí, žijících na úkor pracujících mas ... Nelze zamlčet, že v této skupině nalézáme i jisté procento židů. Avšak byli i jiní souvěrci. Mám na mysli tisíce a tisíce souvěrců, kteří projevili svou bojovou odhodlanost u Sokolova, u Kijeva, u Bílé Cerkve, v Dukelském průsmyku, bok po boku s hrdinnou Rudou armádou ve svazku samostatné československé brigády a vybojovali si rovnoprávnost na krvavých bojištích východní fronty druhé světové války (Kisch, 1951a: 120).

V další úvaze s neméně příznačným názvem Žlutá hvězda vyšla v Mnichově pak Kisch znovu vyjmenoval údajné zrádce „československého lidu“: protisovětsky orientované a politicky naivní západní mocnosti ( $v$ aktualizovaném označení západní imperialisty) a domácí „buržoazii“, jež zradila československý lid, odhodlaný bojovat bok po boku Sovětského svazu:

V Mnichově se ukázalo, že západní imperialisté již neovládají svůj vlastní nástroj - německý a italský fašismus, že se jim vymkl z rukou, ba více, že jsou oni vydáni jemu na milost a nemilost. Nástroj, namirrený proti Sovětskému svazu, obrátil se nejdřive proti vlastnímu pánovi, proti svému duševnímu otci. Mnichovská dohoda nemohla však býti diktátorsky uložena naší vlasti bez vydatné pomoci tuzemské buržoasie, těch Preisů, Batư, Petschků a j. ... Československý lid, masy pracujících a pracující inteligence chtěli v historických zárijových dnech roku 1938 bojovat ... Zase to byla výhradně komunistická strana, která podporovala v každém směru snahy lidu, a zdůrazňovala rázně okolnost, že Sovětský svaz je připraven nám pomoci ... Avšak pomoc Sovětského svazu nebyla naší buržoasií vítána. Ta dala přednost hitlerovskému diktátu za cenu, že zůstanou nedotčeny jejich peněžní žoky (Kisch, 1951b: 464).

Západní demokracie, jak se tehdy říkávalo, planuly nadšením pro Hitlera a Mussoliniho, kteří se tak čacky vyrovnávali s nespokojeností dělníků. Skrytě nebo veřejně obdivovali autoritativní režimy, které zardousily hrdlo tak obávaného mezinárodního komunismu ... Této nenávisti k Sovětskému svazu Hitler a jemu podobní náležitě po dlouhá léta svých tyranií využívali. Proto také i našemu „hradnímu“ křídlu vládnoucí třídy byl Hitler bližší nežli Sovětský svaz ... Tady a dávno předtím byl již učiněn počátek k Mnichovu a tím také k židovské tragédii. Bylo politováníhodné, že také mnozí židovští továrníci a bankéři tehdy nepochopili, že fašismus nesmete jen příslušníky židovských lidových vrstev, ale že se s chutí zmocní také jich i jejich majetků, aby je „arizoval“,

napsal židovský Věstník dvacet let po „Mnichovu“ (Za opravdovou lidskost a za bratrství mezi národy, 1958: 1).

V tehdejší většinové rétorice se ovšem již tehdy zdánlivě překvapivě uplatňoval i silný národní zřetel. Jako leitmotiv zazníval příměr Mnichova a pobělohorské tragédie, $v$ českém myšlení symbolu dějinné tragédie českého národa. ${ }^{9}$ Národní rámec, do něhož byl „Mnichov“ začleněn, významně totiž přispíval i k drtivé kritice Adenauerova Německa a zesílil po vstupu tehdejšího západního Německa (tzv. Německé spolkové republiky) 
do NATO. Naopak důsledky „Mnichova“ pro židovské obyvatelstvo tehdejšího Československa oficiální většinová propaganda takřka nezmiňovala (Soukupová, 2017: 15-16).

\section{Morální narativ ve „zlatých šedesátých“}

„Zlatá šedesátá“ vnesla do již osvědčené interpretace „Mnichova“ jako zrady československého lidu ze strany „buržoazie“, jíž chtěla zabránit pouze komunistická strana, „Mnichova“ jako předehře ke druhé světové válce v důsledku krátkozraké „imperialistické“ protisovětské politiky a pokračování „Mnichova“ v politické praxi západního Německa dvě nová témata: téma Mnichova jako důsledku národnostní politiky první republiky a téma rozštěpu západoněmecké historiografie v otázce jeho interpretace (Soukupová, 2017: 16-18). Právě ve druhém případě můžeme již hovořit o „politickém tání“. To se projevovalo také zlepšením vztahů mezi Československem a západním Německem. V roce 1973 pak západní Německo vyhlásilo nulitu „Mnichova“ (Kubišta, 1988: 7).

V menšinovém tisku byl nadále rozvíjen motiv 15. března 1939 jako důsledku „Mnichova“, respektive „zrady“ buržoazie, která odmítla pomoc Sovětského svazu a kapitulovala (O. H., 1962: 2). V roce 1963, kdy se připomínalo 25. výročí „Mnichova“, zopakoval menšinový Věstník stereotyp o sobeckých západních demokraciích, které se byly schopny na platformě antikomunismu a antisovětismu s Hitlerem domluvit.

Mnichov - jak dokázala historie - byl posledním pokusem evropských

imperialistických zemí o protisovětský pakt před válkou. Po půl roce se rozpadl pro nepřekonatelné rozpory mezi jeho signatáři, a obrátil se i proti nim ... Po komunistech a židech byly určeny k likvidaci celé další národy,

napsal Věstník, který současně ovšem v uvolněnějších politicko-společenských podmínkách apeloval na vytvoření koalice západních demokracií se Sovětským svazem. Mělo jít o jakési pokračování tradice antihitlerovské koalice během druhé světové války (Mnichov po 25 letech, 1963: 1). Novým tématem se stal i trpký osud židovských uprchlíků německého mateřského jazyka, kteří hledali náhražku domova $v$ pozdní první a $v$ tzv. druhé Československé republice:

Z pohraničí se do středu země stěhovaly desítky tisíc obyvatel, v tom i židé, většinou hovořící německy. Tím se zevně stupňoval onen prvek ,němčení, který byl o to bolestnější, že Hitler v Mnichově využil starých rakouských statistik o ,německém‘ obyvatelstvu pohraničních území k podpoře svých nároků, a vědělo se, že ... v nich značný vliv hrála podnikatelská a společenská účast židovských podnikatelů v tomto území ... zevní tlak, zejména na hladinu šovinistických, velmi zjitřených kruhů však nesporně rostl (Skončilo to 15. března 1939, 1969: 7).

\section{Výklad „Mnichova“ v období tzv. normalizace (1969 - 1989)}

„Normalizační“ oficiální interpretace „Mnichova“ byla ve znamení návratu k rétorice přelomu čtyřicátých a padesátých let minulého století, o níž již bylo pojednáno. Leitmotivem se stal výklad „Mnichova“ jako důsledku nenávisti Západu (v časovém označení světového imperialismu) k Sovětskému svazu. Opakován byl leitmotiv zrady „buržoazie“ 
a komunistické strany jako jediné protihitlerovské síly (Soukupová, 2017: 18). Morálním narativem se znovu stává bolavé téma kapitulace. Měli jsme bojovat, to je název jedné z dobových edic dokumentů vzniklých z činnosti Ústředního výboru Komunistické strany Československa v září 1938 (Štěpán, Soukup, 1978). Současně je však otevřeno téma kapitulace „Mnichov“ měl po drtivé porážce pražského jara časově působit především jako důkaz neudržitelnosti „,buržoazní koncepce“ československého státu: „Mnichov prokázal neudržitelnost buržoasní koncepce československého státu. Stal se pro československý lid synonymem zrady domácí velkoburžoasie a západních velmocí, kapitulantství vůdců reformistických stran. Zde začal proces poznání, v němž lid pochopil, že do čela našich národů musí nastoupit dělnická tř́́da, vedená Komunistickou stranou“ (Štěpán, Soukup, 1978: 3). Předzvěstí rozsáhlého komplexu politicko-společenských změn se pak stal rok 1988, kdy padesáté výročí „Mnichova“ zastínilo v menšinové paměti padesát let od „Křištálové noci“ z 9. na 10. listopad 1938 (Noc, která neměla nikdy skončit, 1988: 1).

\section{Závěr}

Po celé poválečné období zůstal „Mnichov“ ve většinové i menšinové interpretaci tragickým mezníkem, který otevřel cestu k nacistické okupaci Československa. Židovská reprezentace se však naprosto absurdně musela bezprostředně po osvobození Československa bránit osočení, že k „Mnichovu“ přispěla i část židovského obyvatelstva, jež se ve sčítáních hlásila $\mathrm{k}$ německé národnosti. Odmítnutí tohoto nařčení se věnovala i v uvolněnějším ovzduší šedesátých let dvacátého století. Po šoa se tak jednoznačně uplatnil židovský princip nedělitelnosti morálky. Po únorovém převratu (1948) se menšinová oficiální rétorika překryla s většinovou. Židovská reprezentace však také, zčásti i v důsledku židovského myšlení, které hledá příčinu nezdaru u sebe, tehdy připustila, že i Židé měli na katastrofě svůj podíl. Židovská „buržoazie“ se př́́mo spojila s československou „buržoaziil“. Rovněž židovští intelektuálové svým váhavým postojem umožnili vítězství reakce. Zatímco ve většinových interpretacích se uplatnil silný národní rámec, menšinová interpretace zůstala striktně stranická, „papežštější než papež“. Domnívám se, že šlo o jeden z důsledků politických procesů a nového vzepětí státního antisemitismu. Osvědčená účelová politizace „Mnichova“ pokračovala i ve „zlatých šedesátých“, kdy se však v oficiální historiografii objevily snahy ukázat nejednotný pohled na „Mnichov" $v$ západoněmecké historiografii. Menšinové stanovisko zdůrazňovalo nutnost sblížení západních demokracií se sovětským blokem, a to $v$ reminiscenci na protihitlerovskou koalici během druhé světové války. „Normalizace“ vrátila diskusi o „Mnichovu“ do období nejtužší totality, současně však v této události našla argument $\mathrm{k}$ socialistickému směrování Československa pod vedením Sovětského svazu jako jediné možné vývojové alternativě. Samostatnou studii by si zasloužil i většinový a menšinový narativ Mnichova po Sametové revoluci (1989). Z hlediska většinové historiografie se setkáváme na jedné straně s úsilím o kritické zmapování „bílého místa“ dějin, se snahou analyzovat selhání politické reprezentace druhé republiky (a je pozitivní, že tento výklad převažuje). Na druhé straně však nevlivný konzervativní badatelský proud vysvětluje konec první republiky jako zákonitý krach liberální demokracie, jež nezvládla sociální a národnostní krize, a odmítá fakt rychlé fašizace druhé republiky. Typická je i jistá bagatelizace protidemokratických aktivit katolických intelektuálů. Českožidovská veřejnost však logicky spojuje „Mnichov“ nejen s destrukcí prvorepublikového liberalismu, ale také, stejně jako 
většina historiků druhé republiky, s 233 až 277000 židovskými oběṫmi nacismu pocházejícími z prvorepublikového Československa.

\section{Referencie}

Bareš, G. (1948). Klement Gottwald - muž proti Mnichovu. Praha: Svoboda.

Bareš, G. (1958). Proti Mnichovu. Komunistická strana Československa v čele lidové obrany demokracie a republiky proti fašismu. Praha: SNPL.

Bednařík, P. (2016). Antisemitismus v českém denním tisku v období druhé republiky. In M. Zoufalá, J. Holý (Eds.), Rozpad židovského života. 167 dní druhé republiky (s. 198221). Praha: Academia.

Beneš, E. (1968). Mnichovské dny. Paměti. Praha: Svoboda.

Čapek, J. (1970). Psáno do mraků. 1939 - 1939. Praha: Československý spisovatel.

Černý, V. (1994) Paměti I. 1921 - 1938. Brno: Atlantis.

Eisner, P. (1946). O tom židovském plevelu. Věstník Židovské obce náboženské v Praze, 8(7), 59.

Engel, Š. (1946). Ratio legis. Věstník Židovské obce náboženské v Praze, 8(3), 18-20.

Frankl, M. (2009). Židé přes palubu. Konstrukce, židovské otázky‘ za druhé republiky. Dějiny a současnost, 31(3), 37-39.

Gebhart, J. a Kuklík, J. (2004). Druhá republika 1938-1939. Svár demokracie a totality $v$ politickém, společenském a kulturním životě. Praha a Litomyšl: Paseka.

Hájek, J. S. (1958). Mnichov. Praha: SNPL.

Hájek, M. (1959). Od Mnichova k 15. březnu. Př́spěvek k politickému vývoji českých zemí za pomnichovské republiky. Praha: Státní nakladatelství politické literatury.

Halas, F. (1940). Torso naděje. Verše. Praha: Fr. Borový.

Holan, V. (1938). Zář́ 1938. Praha: Fr. Borový.

Kárný, M. (1989). Politické a ekonomické aspekty ,židovské otázky` v pomnichovském Československu. Sbornik historický, 36, 171-209.

Kisch, Š. (1951a). Když zrada byla dokonána. Věstník Židovské obce náboženské v Praze, 13(11), 120-121.

Kisch, Š. (1951b). Žlutá hvězda vyšla v Mnichově. Věstník Židovské obce náboženské v Praze, 13(39), 464.

Konec jednoho údobí (1938). Rozvoj, 48(42), 1.

Kreibich, K. (1948). Slovo k židům ve výročí Mnichova. Věstník Židovské obce náboženské v Praze, 10(38), 405-406.

Křen, J. (1958). Mnichovská zrada. Praha: SNPL.

Křen, J. (1963). Do emigrace. Buržoasní zahraniční odboj 1938-1939. Praha: Naše vojsko.

34 Kubišta, V. (Ed.). (1988). Mnichov - k 50. výročí mnichovské tragédie. Na pomoc 
lektorům. Praha: Horizont.

Kudělka, V. (1987). Boje o Karla Čapka. Praha: Academia.

Kuklík, J., Němeček, J., Šebek, J. (2011). Dlouhé stíny Mnichova. Mnichovská dohoda očima signatářù a její dopady na Československo. Praha: Auditorium.

Kuklík, J., Roček, A., Zátka, P. (1969). S Mnichovem za zády. Dějiny a současnost, 11(2), 18-21.

Kural, V. (1994). Místo společenství - konflikt! Češi a Němci ve Velkoněmecké řiši a cesta k odsunu (1938 - 1945). Praha: Ústav mezinárodních vztahů.

Machačová, J. a Matějček, J. (1999). Sociální pozice národnostních menšin v českých zemích 1918-1938. Opava: Slezský ústav Slezského zemského muzea.

Mnichov po 25 letech. (1963). Věstník židovských náboženských obcí $\checkmark$ Československu, XXV(9), 1-2.

Nakonečný, M. (2006). Český fašismus. Praha: Nakladatelství Vodnár.

Noc, která neměla nikdy skončit. (1988, listopad). Věstnik židovských náboženských obcív Československu, 50, 1-2.

O. H. (1962). K 15. březnu 1939. Věstník židovských náboženských obcí $v$ Československu, 24(3), 2.

Pasák, T. (1999). Český fašismus 1922-1945 a kolaborace 1939-1945. Praha: Práh.

Pejčoch, I. (2011). Fašismus v českých zemích. Fašistické a nacionálněsocialistické strany a hnutív Čechách a na Moravě 1922 - 1945. Praha: Academia.

Peroutka, F. (1995). Deníky, dopisy, vzpomínky. Praha: Nakladatelství Lidové noviny.

Pujmanová, M. (1947). Hra s ohněm. Praha: Československý spisovatel.

Rataj, J. (1993). O rasový národ. K proměnám českého nacionalismu v druhé republice. Historie a vojenství, 42(4), 80-94.

Rataj, J. (1994). Proměny českého nacionalismu v druhé republice. Historický obzor, 2 , 40-44.

Rataj, J. (1997). O autoritativní národní stát. Praha: Karolinum.

Rataj, J. (2007). Česká politika v druhé republice - kritický pohled na ,neznámé češství. In M. Pojar, B. Soukupová, M. Zahradníková (Eds.), Židovská menšina za druhé republiky (s. 21-44). Praha: Židovské muzeum v Praze.

Rothkirchen, L. (2005). The Jews of Bohemia \& Moravia. Facing the Holocaust. Lincoln and Jerusalem: University of Nebraska Press and Yad Vashem.

Skončilo to 15. března 1939. (1969). Věstník židovských náboženských obcí $v$ Československu, 31(8), 7-8.

Slovo k židům na Slovensku. (1946). Věstník židovské obce náboženské v Praze, 8(3), 17-18.

Soukupová, B. (2000). Peroutkova Př́tomnost, židé a Židé (1924-1939). Lidé města, 4 , 36-79. 
Soukupová, B. (2007). Češi židé mezi Mnichovem a 15. březnem 1939. In M. Pojar, B. Soukupová, M. Zahradníková (Eds.), Židovská menšina za druhé republiky (s. 84-98). Praha: Židovské muzeum v Praze.

Soukupová, B. (2008). Antisemitismus za druhé republiky: antisemitismus jako jeden ze stavebních kamenů nové identity české společnosti? In V. Tydlitátová (Ed.), Kolokvium o soudobém antisemitismu II (s. 54-80). Plzeň: ADELA - Grafické studio.

Soukupová, B. (2013). Mýty Prahy v krátkém období druhé republiky: Hledání cest k nové identitě české metropole. In B. Soukupová, M. Hroch, P. Salner, K. Pauknerová (Eds.), Cesty urbánní antropologie. Tradice - nové směry - identita (s. 25-71). Praha: Fakulta humanitních studií Univerzity Karlovy v Praze.

Soukupová, B. (2016a). Židé v českých zemích po šoa. Identita poraněné paměti. Bratislava: Marenčin PT.

Soukupová, B. (2016b). „Svár demokracie a totality.“ České myšlení za tzv. druhé republiky (Historickoantropologické úvahy o národní identitě v čase společenské krize). In M. Zoufalá, J. Holý (Eds.), Rozpad židovského života. 167 dní druhé republiky (s. 13-51). Praha: Academia.

Soukupová, B. (2016c). Reflexe Mnichova a českožidovské strategie v období tzv. druhé republiky. In M. Zoufalá, J. Holý (Eds.), Rozpad židovského života. 167 dní druhé republiky (s. 164-197). Praha: Academia.

Soukupová, B. (2017). Mnichov jako české národní trauma: období po druhé světové válce. In B. Soukupová, R. Godula Węcławowicz a kol. (Eds.), Národy - města - lidé traumata (s. 9-24). Praha: Fakulta humanitních studií Univerzity Karlovy.

Šebek, J. (2016). Katolicismus a antijudaismus na konci 30. let a za druhé republiky v českých zemích. In M. Zoufalá, J. Holý (Eds.), Rozpad židovského života. 167 dnídruhé republiky (s. 52-74). Praha: Academia.

Štěpán, F. a Soukup, J. (Eds.). (1978). Měli jsme bojovat. Zápisy z jednání politického byra ÚV KSČ v zárí 1938. Praha: Ústav marxismu-leninismu Ústředního výboru KSČ.

Ústav pro mezinárodní politiku a ekonomii. (1959). Kdo zavinil Mnichov. Sborník z mezinárodního vědeckého zasedání k 20. výročí Mnichova. Praha: Státní nakladatelství politické literatury.

Za opravdovou lidskost a za bratrství mezi národy. (1958). Věstnik židovských náboženských obcív Československu, 20(10), 1-2. 